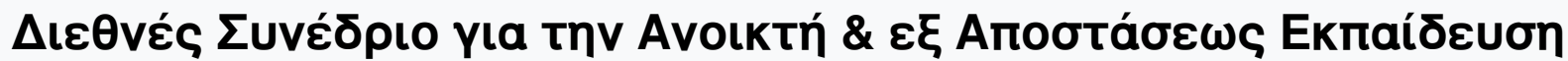

Tóp. 10, Ap. 1B (2019)

\section{ПPAKTIKA}

$10^{C}$ EYNEAPIO TIA THN ANCIKTH \& E AחCETALERI EKMAIAEYLH

를

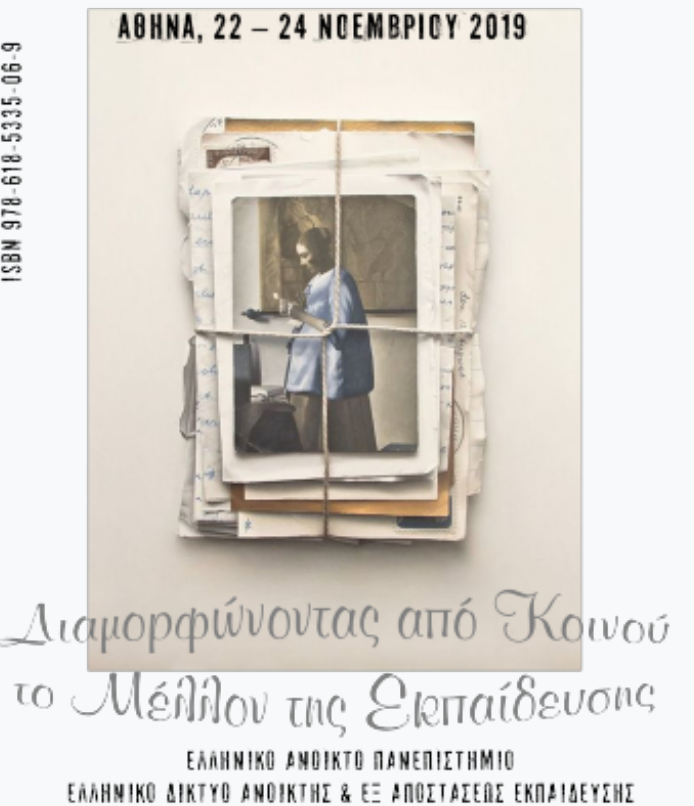

When self knowledge meets digital learning: $\mathbf{5 0}$ plus women "speak" about sexuality

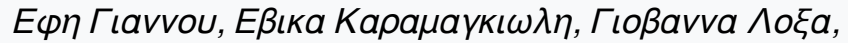

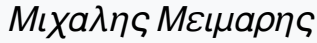

doi: $10.12681 /$ icodl.2435

\section{TOMOL 1, MEPCE B}




\title{
When self knowledge meets digital learning: 50 plus women "speak" about sexuality
}

\author{
Efi Gianou \\ University of Athens \\ efigiannou@gmail.com
}

Giovanna Loxa

University of Athens

gioloxa@gmail.com

\author{
Evika Karamagioli \\ University of Athens \\ karamagioli@gmail.com \\ Michalis Meimaris \\ University of Athens \\ mmeimaris@media.uoa.gr
}

\begin{abstract}
Digital Storytelling as an educational methodology and instructional technology, offers a combination of technical and non-technical skills that are at the heart of the lifelong learning concept and the much needed 21st century digital skills. Additionally, it can be considered as a mean that potentially can empower sensitive social groups like middle age women to express themselves. On the one hand designing and communicating information via storytelling requires participants to deepen their understanding of content while increasing visual, sound, oral language, creativity, and thinking skills. On the other hand, designing and communicating information via storytelling empowers the self expression and strengthens civic skills and relevant behavioral patterns. In the case presented women of 50 plus create digital stories (that will be showcased) using multi modal communication ( narration, text, photos, video, music etc) trying to discuss and figure out the role and importance of sexuality in their lives. The digital storytelling methodology allowed them to express themselves about "sensitive personal matters" they experienced, to break through some of the selfinflicted isolation associated with them and thus increased their self-confidence and the connection between each other in an effective and meaningful way on topics as motherhood, marriage, illness, partners, loneliness, sexuality.
\end{abstract}

Note: During the presentation of the case, indicative stories produced will be viewed so as to discuss in open air their educational value in terms of lifelong learning.

Keywords: digital storytelling, self-expression, multimodal communication

\section{Introduction}

As contemporary economies are more and more becoming service-based, digital literacy and social skills are becoming increasing popular. Skills that involve interaction, collaboration, flexibility and adaptability, initiative and self-direction, critical thinking and problem solving, communication collaboration and creativity along with ICT skills are of high demand in the 21st-century job market (van Laar et all, 2017).

Digital Storytelling as an educational methodology and instructional technology, offers a combination of technical and non technical skills that are at the heart of the lifelong learning concept and the aforementioned much needed 21 st century digital skills. Additionally it can be considered as a mean that potentially can empower sensitive social groups like middle age women to express themselves. On the one hand designing 
and communicating information via storytelling requires participants to deepen their understanding of content while increasing visual, sound, oral language, creativity, and thinking skills. On the other hand designing and communicating information via storytelling empowers the self expression and strengthens civic skills and relevant behavioral patterns.

According to the DESI Report for 2018, in Greece only $46 \%$ of people have basic digital skills, much lower than the average rate of the EU (57\%). Also, according to the Women Digital Scoreboard for 2018 , Greece is ranked in the $26^{\text {th }}$ position with a score of 36.1 compared to 49.1, the average rate of the EU. Additionally the employments rates for the specific age group are very low.

Clearly there is an need in the country for actions to increase the participation of women in digital era, challenging digital gender stereotype and promoting digital skills and education.

The article discusses the role of digital storytelling as a process that can potentially enhance digital skills and social competences of women 50 plus in a non stereotypic and innovative way. We therefore present the case of 4 women of 50 plus that were asked to create digital stories using multi modal communication (narration, text, photos, video, music etc) trying to discuss and figure out the role and importance of sexuality in their lives.

\section{Methodology}

The sample was selected on the basis of two criteria, sex and age. More specifically, the limitations set out were for the choice of female sex only and as a subdivision of this restriction the age limit was set, which should be over 50 years. These criteria were deliberately set because of the aim of the research and the focus on specific sample characteristics to answer research questions and assumptions. The participants in the present study are 4 women from 50 to 58 years of age.

Regarding the number of the group (4 participants), this was defined on the basis of the data analysis approach (narrative analysis) and the advantage offered by qualitative surveys as they aim at in-depth analysis of subjects rather than generalization. It was also set as a result of the limitations that arose regarding the difficulty of finding people meeting the criteria that were set, as well as the timeframe needed to create digital narratives.

Below are some facts about each participant. The objective of presenting the participant's data is to help the reader to understand the individual context of the participants and to draw their own conclusions from each digital storytelling based on the individual context. The names of the participants were codified to ensure their anonymity and privacy.

\begin{tabular}{|l|l|l|l|l|}
\hline Name & Age & Marital status & Children & Education \\
\hline$\Sigma 1$ & 52 & Married & 2 & Higher Education \\
\hline$\Sigma 2$ & 50 & Married & 2 & Higher Education \\
\hline$\Sigma 3$ & 55 & Married & 2 & Secondary Education \\
\hline$\Sigma 4$ & 58 & $\begin{array}{l}\text { Reconciliation } \\
\text { agreement }\end{array}$ & 0 & Higher Education \\
\hline
\end{tabular}

Table 1: Sample characteristics 
S1 is 52 years old and lives in the northern suburbs of Athens. She is married and has two adult children. He is a graduate of Higher Education and works as a freelancer. S2 is 50 years old and lives in the southern suburbs of Athens. She is married and has two underage children. He is a graduate of Higher Education and works as a freelancer. S3 is 55 years old and lives in Athens. She is divorced from her first marriage; she has an adult (student) son from her first marriage and a minor daughter from her second marriage. She lives with her husband and her two children. She is a graduate of Secondary Education and is an entrepreneur. S4 is 58 years old and lives in Athens. It coincides with her new partner having recently made a cohabitation agreement.

Digital storytelling is a curriculum that uses technology with communication, literacy skills, and language arts. It includes the use of technological devices such as the computer and Internet to morphs words with narration. Digital stories include mixtures of computer-based images, text, recorded audio narration, video clips and music. They are organized based on the following 7 elements: point of view, dramatic question, emotional content, gift of your voice, power of the soundtrack, economy, and pacing. The sample was asked to create a digital story each focusing on the theme "50 plus women "speak" about sexuality". During a two month period in 2019, the sample had a series of 4 meeting with the authors of the paper acting as facilitators and trainers. During these meetings that has a 2 hour duration each, they discussed, learned and experimented on how to technically create the stories, they experimented on the digital tools such as movie maker and adobe premiere Pro CS6 , learned how to do the recording, on how to search and identify sounds and videos on the web, how to incorporate them in a video. They also learned about the digital capacities smartphone (they all had) have. They also shared experienced and discussed their key ideas as well as the script of their stories. Once the stories were completed they were are presented and discussed openly to the authors and the sample.

Due to the sensitive character of the subject the written consent of the sample was gathered, the management and protection of personal data and privacy in the web was also one of the issues the authors discussed with and gave guidelines to the sample.

\section{Results}

Our findings suggest that the digital storytelling process was fruitful in several levels. With regards to the digital skills gained, the main remark is that although all participants had social, networking, email and smartphones, they felt not familiar with technology. They all considered the creation of their digital story something valuable that gave them skills and showed them things they "could do with their phones and laptops they would never believe they could do" .

Thus Digital storytelling has proved to be a technological enabler for constructive dialogue, unleashing students' creativity and developing their self-expression.

Important skills were acquired or improved: the technical and artistic skills of how to produce a digital story; the cultural and social abilities of how to understand themselves and the world around them, to act and to react within it; the civic awareness of how to use story for community change initiatives (Meimaris et al., 2017).

The digital storytelling methodology allowed them to express themselves about "sensitive personal matters" they experienced, to break through some of the selfinflicted isolation associated with them and thus increased their self-confidence and the connection between each other in an effective and meaningful way on topics as motherhood, marriage, illness, partners, loneliness, sexuality. 
However, we have observed that the sample had some initial difficulties in "understanding" the meaning of this methodology, especially to find the key message and to link it with their personal life and experience.

The majority of the sample found it to be a wholesome experience creating mutual levels of trust, bonding and sharing between themselves, the rest of the sample and the authors.

The 3 elements they all mentioned to comment the whole workshop experience were "motivation, encouragement, sharing". It also came across comments and reasoning such as:

- 'I can really use what I have learned in my everyday job '

- "I was a very introvert person and could not express myself to the audience up to now"

- "It is a really powerful experience to be able to express myself like that and communicate with the others just like my grandchildren do it with their friends

- "Technology isn't so difficult after all"

- "With a smartphone you can rule the world literally from what I see now"

S1 said, "The friend told me that I must continue to deal with the digital storytelling because I can say a lot". Her children asked her if she or the researcher made it, and they were initially making fun of her, and they were angry because she could not do that. When she made them known that she had made the script and the narrative, they told her they did not expect to be able to do so. She laughs, she told the researcher, "Can you get my premier to make videos? Show me the basics again, I do not want to tell my kids to do it, I want to see that I do it myself."

The case of S2 at the same time after sharing and commenting shows that she was thrilled and excited that she managed to make a story in this way. She did not expect she could make a "video" on her own, and eventually if she tries everything, she can do it. In fact, her husband gave her a video camera to go on as he told her "you have talent". The same time her children showed the video to their friends commented that their mom "does not only use social".

S3 reported that her friends were identified and felt "strong emotional by her storytelling ". She told them they could write those scripts and make stories. She also said she felt happy as she did something for herself and feels very proud of the time she devoted. Her son on the phone joked with her and said, "It's not for you, you're great." The participant told the researcher "Why am I not for them? What's going on to say I'm great? Everything you can do if you want it and remember yourself. I am not only a mom, nor a husband I am the I ".

S4 said that after this experience she wants to make her lap top and make video "if I can make it because it's a bit difficult, I do not know if I remember all that, but I want to make videos for my plaque." Moreover, she did not expect her to enjoy the process and the outcome, she accepted to help the researcher because she knew how difficult it was to find a sample and first saw it as a chore, "I'll get it out of the way," but on the way she realized that she the process touched her emotionally but also practically (to continue to deal with).

Two months after the completion of the digital storytelling experience the sample was asked to evaluate the skills and competences that they considered they gained. The viewpoints are summarized below. They are based on the 2012 National Research Council (U.S.). classification. 


\begin{tabular}{|c|c|c|c|c|}
\hline $\begin{array}{l}\text { SKILL \& } \\
\text { COMPETENCES }\end{array}$ & $\mathrm{S} 1$ & $\mathrm{~S} 2$ & S3 & S4 \\
\hline $\begin{array}{l}\text { Cognitive ( ie critical } \\
\text { thinking, reasoning } \\
\text { and argumentation, } \\
\text { ICT literacy, oral and } \\
\text { written } \\
\text { communication, and } \\
\text { active listening, } \\
\text { creativity) }\end{array}$ & $\begin{array}{l}50 \% \\
\text { improvement } \\
\text { after the } \\
\text { digital } \\
\text { storytelling } \\
\text { exercise }\end{array}$ & $\begin{array}{l}60 \% \\
\text { improvement } \\
\text { after the } \\
\text { digital } \\
\text { storytelling } \\
\text { exercise }\end{array}$ & $\begin{array}{l}45 \% \\
\text { improvement } \\
\text { after the } \\
\text { digital } \\
\text { storytelling } \\
\text { exercise }\end{array}$ & $\begin{array}{l}50 \% \\
\text { improvement } \\
\text { after the } \\
\text { digital } \\
\text { storytelling } \\
\text { exercise }\end{array}$ \\
\hline $\begin{array}{l}\text { Intrapersonal (ie } \\
\text { flexibility, artistic and } \\
\text { cultural appreciation, } \\
\text { appreciation for } \\
\text { diversity, adaptability, } \\
\text { continuous learning, } \\
\text { intellectual interest } \\
\text { and curiosity, self } \\
\text { expression, self } \\
\text { empowerment) }\end{array}$ & $\begin{array}{l}70 \% \\
\text { improvement } \\
\text { after the } \\
\text { digital } \\
\text { storytelling } \\
\text { exercise }\end{array}$ & $\begin{array}{l}60 \% \\
\text { improvement } \\
\text { after the } \\
\text { digital } \\
\text { storytelling } \\
\text { exercise }\end{array}$ & $\begin{array}{l}65 \% \\
\text { improvement } \\
\text { after the } \\
\text { digital } \\
\text { storytelling } \\
\text { exercise }\end{array}$ & $\begin{array}{l}65 \% \\
\text { improvement } \\
\text { after the } \\
\text { digital } \\
\text { storytelling } \\
\text { exercise }\end{array}$ \\
\hline $\begin{array}{l}\text { Interpersonal (ie } \\
\text { communication, } \\
\text { collaboration, } \\
\text { cooperation, } \\
\text { teamwork, } \\
\text { interpersonal skills, } \\
\text { self presentation, } \\
\text { social influence with } \\
\text { others) }\end{array}$ & $\begin{array}{l}55 \% \\
\text { improvement } \\
\text { after the } \\
\text { digital } \\
\text { storytelling } \\
\text { exercise }\end{array}$ & $\begin{array}{l}65 \% \\
\text { improvement } \\
\text { after the } \\
\text { digital } \\
\text { storytelling } \\
\text { exercise }\end{array}$ & $\begin{array}{l}55 \% \\
\text { improvement } \\
\text { after the } \\
\text { digital } \\
\text { storytelling } \\
\text { exercise }\end{array}$ & $\begin{array}{l}60 \% \\
\text { improvement } \\
\text { after the } \\
\text { digital } \\
\text { storytelling } \\
\text { exercise }\end{array}$ \\
\hline
\end{tabular}

Table 1 Sample perspectives of Digital Storytelling added value of skills and competences

\section{Discussion}

Digital Storytelling has proved to be an effective pedagogical tool and instructional technology (Juppi, 2015). But it can be much more than that. It can be a powerful mean of communicating and connecting each other in an effective and meaningful way. Generator of constructive user experiences it is defined as "conversational media" (Couldry, 2008)

In the sense that it is both a technique to increase understanding across generations, ethnicities and other divides, and at the same time a tool to promote civic commitment, education, professional reflection and corporate communication (Lambert, 2006).

Digital Storytelling under this angle is not only about creating stories as multimodal multimedia narratives. It is to be involved in a facilitated discussion and participatory group process during their creation and last but not least is about sharing them. It provides a virtual space for individuals to reflect past and present by looking at their own lives and their interactions with people through a critical eye. Therefore, they strengthen their social and emotional intelligence, they place themselves in the civic affairs sphere. They understood that they are more or less an active apart of it, their attitudes and action have a positive or negative impact and they have the potential to act rather than to endure social change

The graph that follows by Niemi et all (2014) gives a holistic representation of what digital storytelling can offer ranging from technical (digital knowledge and skills) to social (soft skills). 


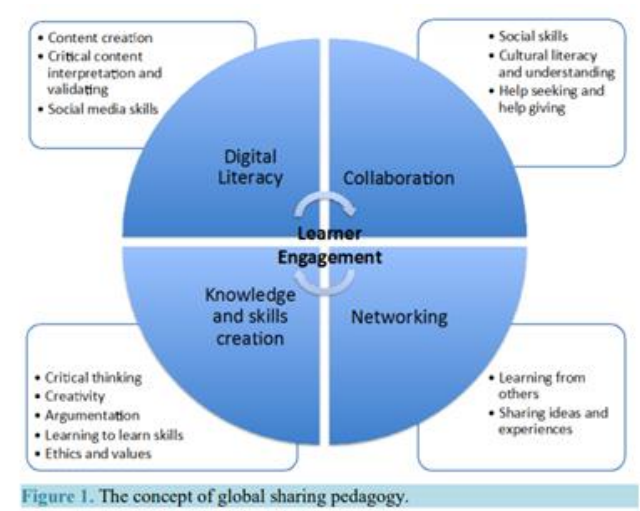

Graph 1 Digital Storytelling assets

In the Greek sociopolitical and economic set up where digital skills are missing and the people 50 plus find themselves missing opportunities to be socially active and be included in the productive generations, the use of tools and methodologies such as digital storytelling can be beneficial.

\section{Conclusion}

Digital storytelling has a strong potential both as a educational and dialectic tool (Meimaris et al, 2017) but also as a social activity. According to Warschauer (2004) the best way to develop the multiple literacies required in the information age and to benefit from ICT, is to use them for tackling real problems and for engaging in new communities. Thus, even if Digital Storytelling activities are usually short-term interventions, they may have long-term impacts for the individuals social (Juppi, 2015) and phycological evolution of those involved (Meimaris et al., 2017).

\section{NOTE}

During the presentation of the paper, all 4 stories will be showcased.

\section{References}

Couldry, N. (2008), Digital Storytelling, Media Research and Democracy: Conceptual Choices and Alternative Futures. In: S Jones and K Lundby, eds. Digital Storytelling, Mediatized Stories: Self representations in New Media. 52 New York, Bern, Berlin, Bruxelles, Frankfurt am Main, Oxford, Wien: Peter Lang, pp. 41-60. ISBN 978-1-4331-0274-5

Ester van Laar, Alexander J.A.M. van Deursen, Jan A.G.M. van Dijk, Jos de Haan, The relation between 21 -century skills and digital skills or literacy: A systematic literature review, The relation between 21st-century skills and digital skills or literacy A systematic literature review (2017), doi: 10.1016/j.chb.2017.03.010

Greece (2019) DIGITAL SKILLS FOR DIGITAL GREECE Action Plan 2019 for the promotion of innovation and digital skills Available at http://www.nationalcoalition.gov.gr/wpcontent/uploads/2019/02/NC_Action_Plan_2019_en.pdf

Juppi, P. (2015). ”Getting Empowered through Digital Storytelling: Using Digital Storytelling for Skill Building and Self-Reflection at GROW Leadership Academy of RLabs Iringa." In Shaping the Perspectives of Future Journalists - JOCID 2007-2015: Journalism for Civic Involvement, Democracy and Development, edited by Susanna Pyörre, and Pia Alanko, 136-151 Turku: Turku University of Applied Sciences. http://julkaisut.turkuamk.fi/isbn9789522165695.pdf

Karamagioli, E, Laborderie,A, Michael Meimaris.M (2018) Discussing civic values and concerns: Digital Storytelling as a powerful media technique and practice. Digital Storytelling Conference “Current Trends in Digital Storytelling: Research Practices”, Sep 2018, Zakynthos, Greece 
Khebbaz, S. (2016). "Youth media and social change: Using digital storytelling as a tool that engages youth to become change agents". Capstone Collection.

Lambert, J. (2006). Digital Storytelling: capturing lives, creating community, 2nd edition, Berkeley, CA: Digital Diner Press.

Lambert, J. (2007). Digital Storytelling CookBook. Berkeley: Digital Diner Press.

Meimaris, M., Karamagioli, E., Laborderie A., (2017). "Digital storytelling as an educational dialectic model: results from a project on contemporary forms of Odyssey", in Azémard G. et Théorêt Y. (dir), Humanisme numérique : valeurs et modèles pour demain ?, Actes du colloque international organisé par le réseau international des chaires UNESCO en communication ORBICOM, Paris les 26-28 octobre , t. 3. Paris, Éditions de l'Immatériel.

National Research Council (U.S.)., Pellegrino, J. W., Hilton, M. L., National Research Council (U.S.)., National Research Council (U.S.)., \& National Research Council (U.S.). (2012). Education for life and work: Developing transferable knowledge and skills in the 21 st century.

Niemi, H., Harju, V., Vivitsou, M., Viitanen, K., Multisilta, J., \& Kuokkanen, A. (2014). Digital Storytelling for 21st -Century Skills in Virtual Learning Environments. Creative Education, 5, 657-671.

Sawyer, C. \& Willis, J. (2011) Introducing Digital Storytelling to Influence the Behavior of Children and Adolescents, Journal of Creativity in Mental Health, 6:4,274-283

Šparavalo, D. (2014). "Citizenship in Bosnia and Herzegovina - visual stories of change". Available at http://www.digitalneprice.net, Retrieved 25.8.2018

Warschauer, M. (2004). Technology and Social Inclusion. Rethinking the Digital Divide (pp 124-125). Cambridge, MA: The MIT Press. 